\title{
The Effect of Remittance, Consumption, and FDI on Economic Growth in ASEAN Countries
}

\author{
By: \\ Mega Mariska*), Lies Maria Hamzah, Arivina Ratih \\ Economics and Business, University of Lampung \\ ${ }^{*}$ Corresponding Author: megamariska54@gmail.com
}

Submission: August 10, 2021; Accepted: September 30, 2021

\begin{abstract}
One of the main indicators seen in reviewing the relationship between international workers and economic growth is remittances. Remittances obtained from workers abroad are one of the major sources of finance for developing countries. Remittances are also a source of finance in increasing migrant household incomes which encourage improved consumption which will affect economic growth. This study was conducted to explore the impact of migrant remittances, consumption and FDI on economic growth in 10 ASEAN countries using annual panel data from 2015-2019. This study uses panel data regression analysis with the Random Effect Model (REM) approach. The results showed that remittances, consumption and FDI positively and significantly contributed to economic growth in 10 ASEAN countries. Significant contribution of migrant remittances in economic growth if their use is directed to more productive sectors such as use in the investment sector can help the economies of ASEAN countries to maintain and increase economic growth. The government needs to improve the quality of migrant workers through education because a high level of education will affect the level of wages received by migrants and will have an impact on increasing remittances. The limitation in this study is the use of limited data, for 2020 it is not included in the data set used in the analysis. For this reason, further research should use 2020 data because in 2020 there be a new phenomenon, namely COVID-19 which can be traced to the impact of this phenomenon on remittances.
\end{abstract}

Keywords: Remittances, Migrant, Economic Growth, Panel Data.

ABSTRAK
Indikator utama yang dilihat dalam meninjau hubungan antara tenaga kerja
internasional dengan pertumbuhan ekonomi salah satunya adalah dengan pengiriman
uang yang berasal dari migran ke negara asal migran atau biasa disebut sebagai
remitansi. Remitansi yang diperoleh dari tenaga kerja di luar negeri merupakan salah satu
sumberkeuangan yang besar untuknegara berkembang. Remitansi juga menjadisumber
keuangan dalam meningkatkan pendapatan rumah tangga migran yang mendorong
perbaikan konsumsi yang akan berpengaruh pada pertumbuhan ekonomi. Penelitian ini
dilakukan untuk mengeksplorasi dampak remitansi, konsumsi dan FDI terhadap
pertumbuhan ekonomi di 10 negara ASEAN dengan menggunakan data panel tahunan
dari 2015-2019. Penelitian ini menggunakan analisis regresi data panel dengan
pendekatan Random Effect Model (REM). Hasil penelitian menunjukkan bahwa remitansi,
konsumsi dan FDI secara positif dan signifikan berkontribusi positif dalam pertumbuhan
ekonomi di 10 negara- negara ASEAN. Kontribusi yang signifikan dari remitansi migran
dalam pertumbuhan ekonomi jika penggunaannya diarahkan ke sektor yang lebih
produktif seperti penggunaan di sektor investasi dapat membantu perekonomian negara-


negara ASEAN untuk mempertahankan dan meningkatkan pertumbuhan ekonomi. Pemerintah perlu meningkatkan kualitas pekerja migran melalui pendidikan karena tingkat pendidikan yang tinggi akan mempengaruhi tingkat upah yang diterima oleh para migran dan akan berdampak pada peningkatan remitansi. Keterbatasan dalam penelitian ini adalah penggunaan data yang terbatas, untuk tahun 2020 tidak termasuk dalam kumpulan data yang digunakan dalam analisis. Untuk itu, penelitian selanjutnya sebaiknya menggunakan data tahun 2020 karena pada tahun 2020 ada fenomena baru yaitu COVID-19 yang dapat ditelusuri dampak fenomena tersebut terhadap remitansi.

Kata Kunci: Remitansi, Migran, Pertumbuhan Ekonomi, Data Panel

\section{INTRODUCTION}

Economic growth is an indicator of the success of development in an economy. The progress of an economy is determined by the amount of growth indicated by changes in national output (Dewi et al., 2013). Economic growth is central in the economic life of all countries in the world as well as ASEAN countries, one of the efforts made by ASEAN countries in increasing economic growth is economic integration through the ASEAN Economic Community (AEC). The consequence of economic integration is that each country must simplify the system in granting permits and facilitate the entry and exit of international workers involved in trade in goods, services and investment (Winantyo et al., 2015).

Introduction presents the background, reason of the research, problem, research gap, research objectives clearly stated so that the reader can understand and evaluate the results achieved from the research conducted without having to read the previous publications related to the relevant topic. Use literatures that can really support disclosure of disclosed backgrounds. Introductory chapter should contain the background and purpose of the study.

One of the main indicators seen in reviewing the relationship between international workers and economic growth is remittances originating from migrants to the country of origin of migrants (Ukhtiyani \& Indartono, 2020). Remittance has become a new financial phenomenon and is one of the most important sources of funds that has no effect on the world economy (Meyer \& Shera, 2017). (Akay et al., 2014) explains that remittances can increase capital allocation, increase financial development and accelerate economic growth. Remittances are remittances that become big cash for the whole world, when workers in the country have high mobility, remittances are also abundant (Abida \& Sghaier, 2014). 


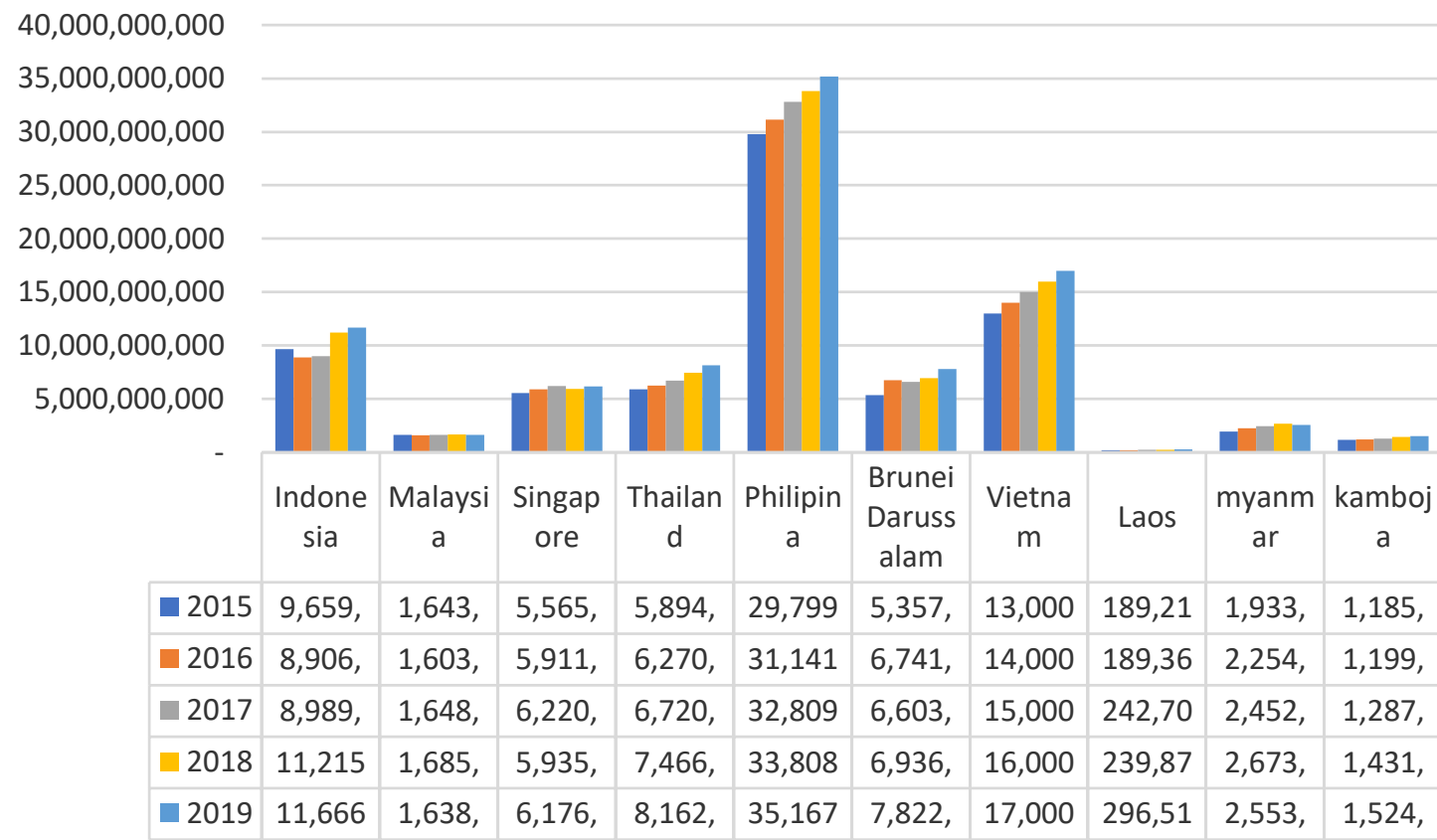

Figure 1. Remittances from ASEAN Countries 2015-2019

Source : Worldbank

Figure 1 shows that the largest number of remittances among ASEAN countries in 2015 was the Philippines, which amounted to 29,799 USD or $9.72 \%$ of the total GDP. The number of remittances in the Philippines continues to increase every year until 2019 the amount of remittances is 35,167 USD. Then the lowest remittance in 2015 was Laos, which was 189 USD or $0.54 \%$ of total GDP.

There is increasing interest in and demand for remittance flows in developing countries, although experts have expressed differing views on the implications for economic growth and development. On the one hand, remittances are believed to be a catalyst for accelerated economic growth and development because they increase household purchasing power and serve as additional working capital for beneficiary households who often reside in low-income countries. Inflows of international remittances are also important to protect developing country governments in managing fiscal and budget deficits towards macroeconomic stability and real growth.

On the other hand, it is feared that the flow of international remittances could destabilize the economies of developing countries through excess demand which results in price increases, weakening international competitiveness of exports due to the appreciation of the real exchange rate. International migrant remittances proved statistically significant in driving endogenous growth, although marginally financial developments did not directly lead to growth, unless they succeeded in attracting non-debt foreign capital in the form of remittances through the formal sector. Financial developments lead to a flow of migrant remittances which have a positive impact on growth (Adenutsi, 2011).

Several previous studies on the relationship between remittances and economic growth showed mixed results. Research conducted by Abduvaliev \& Bustillo (2020) states that remittances have a positive and significant effect on economic growth in the former Soviet Union (CIS) countries in addition to the results of research conducted by Tangtipongkul \& Khiev (2019), Cooray (2012), Shera \& Meyer(2013), Adenutsi(2011)also showed a positive and significant effect. However, contradictory results are shown in research conducted by Ukhtiyani \& Indartono (2020) which states that remittances have no effect on economic growth.

Remittances obtained from workers abroad are one of the major sources of finance for developing countries. Incoming remittances become an income injection for migrant families in the area of origin so that it can increase the purchasing power of lower-class households (Permatasari \& 
Sugiharti, 2017). Remittances are also a source of finance in increasing migrant household incomes, remittances encourage improvements made by households in daily consumption, spending on education, health, and other costs, so that it will affect economic growth (Afriska et al., 2019).

In previous research conducted by Shera \& Meyer (2013) showed that consumption had a negative and significant effect on economic growth. However, subsequent research Meyer \& Shera (2017) shows that consumption has a positive and significant effect on economic growth.

Not only consumption, but investment is also very important in economic growth. Investment is a macro variable that affects economic growth, this is because investment will shape the allocation of capital. Developing countries that really need capital for their development, especially if domestic capital is not sufficient, will generally attract foreign investment. FDI (Foreign Direct Investment) is seen as a more effective way to encourage economic growth of a country where foreign capital can make a good contribution to the process of economic growth. Research conducted by Cooray (2012), Shera \& Meyer (2013), Adenutsi (2011)shows a positive and significant effect of FDI on economic growth. However, contradictory results are shown in research conducted by Ukhtiyani \& Indartono (2020) which states that FDI has no effect on economic growth. Based on this background, the purpose of this study is to analyze the effect of remittances, consumption and FDI on economic growth.

\section{METHODS}

This study uses a quantitative approach to analyze the effect of remittances, consumption and FDI as independent variables on economic growth as the dependent variable. The data used is panel data combining time series and cross section data with a cross section of 10 ASEAN countries, namely Indonesia, Vietnam, Myanmar, Brunei Darussalam, Cambodia, Laos, Malaysia, Singapore, Thailand, and the Philippines. According to Gujarati (2013) panel data is best for detecting and measuring impacts that simply cannot be seen in pure cross section data or pure time series. In the use of panel data, some of the interception assumptions that appear show that the parameter estimation is increasingly complex, so it is necessary to choose an estimation technique using the Chow test, Hausman test and Lagrange multipler (Widarjono,2013). The data used include the amount of remittances in US\$, the percentage of household consumption to GDP, the amount of FDI in US\$ and the percentage of economic growth with the research period from 2015 to 2019. The estimation model in this study is as follows:

$$
E G_{i t}=\beta_{0}+\beta_{1} R E M_{i t}+\beta_{2} C O N_{i t}+\beta_{3} F l_{i t}+e_{i t}
$$

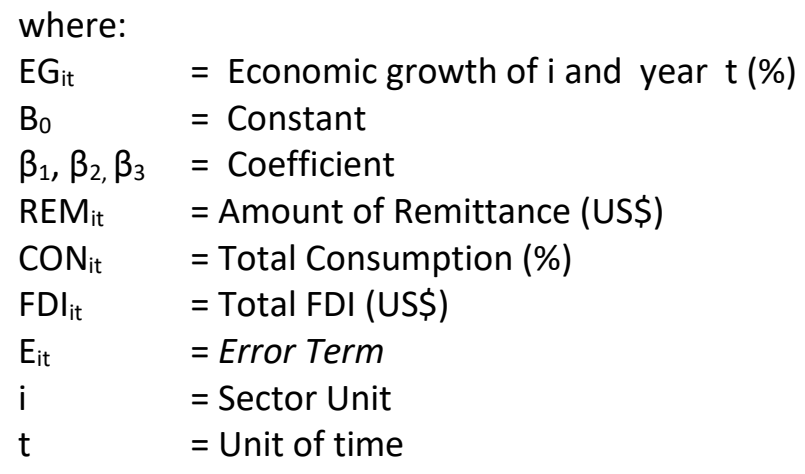

\section{RESULTS AND DISCUSSIONS}

Based on the estimation results of the model of the effect of remittances, consumption, FDI on economic growth in ASEAN countries, namely Indonesia, Vietnam, Myanmar, Brunei Darussalam, Cambodia, Laos, Malaysia, Singapore, Thailand, and the Philippines which is processed by panel data regression, the results show the results of the test. The Lagrange multiplier (LM) has a probability value of 0.0423 which is smaller than the $5 \%$ significance level, thus concluding that the best model that can be used in analyzing this research is the Random Effect Model (REM). The results are obtained in Table 1. 
Table 1. Model Estimation Results Using Random Effect Method

\begin{tabular}{|c|c|c|c|c|}
\hline \multicolumn{5}{|c|}{ Variabel Dependen EG } \\
\hline Variable & Coefficient & Std. Error & t-Statistic & Prob. \\
\hline $\mathrm{C}$ & 0.674252 & 0.107173 & 6.291217 & 0.0000 \\
\hline REM & 17.18409 & 8.054313 & 1.380060 & 0.0174 \\
\hline CON & 24.08150 & 0.032243 & 4.887442 & 0.0000 \\
\hline FDI & 19.49106 & 2.619807 & 5.698341 & 0.0000 \\
\hline \multicolumn{3}{|c|}{ Effects Specification } & S.D. & Rho \\
\hline Cross-section random & & & 0.021681 & 0.7400 \\
\hline Idiosyncratic random & & & 0.012852 & 0.2600 \\
\hline \multicolumn{5}{|c|}{ Weighted Statistics } \\
\hline R-squared & 0.857412 & \multicolumn{2}{|c|}{ Mean dependent var } & 0.884244 \\
\hline Adjusted R-squared & 0.848113 & \multicolumn{2}{|c|}{ S.D. dependent var } & 0.060704 \\
\hline S.E. of regression & 0.023658 & \multicolumn{2}{|c|}{ Sum squared resid } & 0.025746 \\
\hline F-statistic & 92.20266 & \multirow{2}{*}{\multicolumn{2}{|c|}{ Durbin-Watson stat }} & 1.755223 \\
\hline Prob(F-statistic) & 0.000000 & & & \\
\hline \multicolumn{5}{|c|}{ Unweighted Statistics } \\
\hline R-squared & 0.970767 & \multicolumn{2}{|c|}{ Mean dependent var } & 3.450809 \\
\hline Sum squared resid & 0.077743 & \multicolumn{2}{|c|}{ Durbin-Watson stat } & 0.515708 \\
\hline
\end{tabular}

\section{Source: Eviews 9}

From Table 1, it is known that remittance (REM), consumption (CON), foreign direct investment (FDI) variables are variables that affect economic growth in ASEAN countries. The model from the panel data regression processing in Table 1 has met the economic test because the sign of the coefficients in each independent variable is the same as the hypothesis based on existing economic theory and previous research.

The classical assumption test on the model has been fulfilled, including the multicollinearity test where the multicollinearity test can be known from the comparison of probability values and correlation matrices between variables. In the remittance model for economic growth, the R-Square value is 0.857412 and there are all significant independent variables, which means that the model is free from multicollinearity. Multicollinearity problems can occur if the R-Square value is high but the independent variables are not significant. In addition, the R-Square value also shows that 85.74 percent of the independent variables can affect the dependent variable in the model. Then the next classic assumption test is heteroscedasticity, in table 1 the results show that the Sum Square Resid value in the Unweighted Statistics is 0.077743 which is greater than the Sum Square Residual in the Unweighted Statistics is 0.025746 , meaning that there is no heteroscedasticity problem.

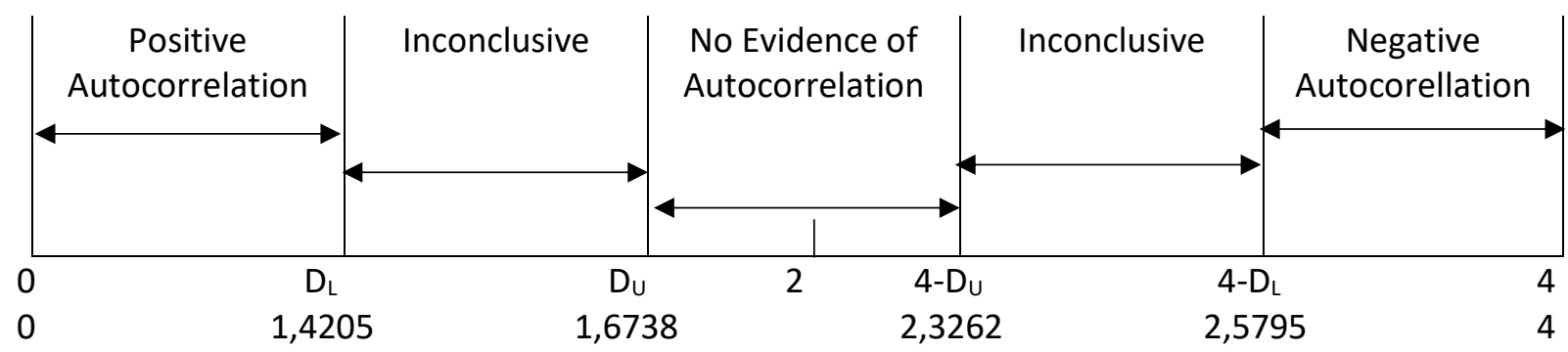

Figure 2. Durbin Watson Test

The Durbin Watson's calculated statistical value $d=1.755223$, while the critical value of $d$ at alpha $5 \%$ with the number of observations as many as 50 and the number of variables 4 known $D_{L}$ value $=1.4205$ and $D_{U}$ value $=1.6738$. While the value of $4-D_{U}=2.4362$ and the value of $4-D_{L}=2.5795$. Because the statistical value lies between $D_{\cup}$ and $4-D_{\cup}$, it can be said that there is no autocorrelation 
problem. There is no correlation value between independent variables that exceeds the R-Square value, so the estimation results do not experience autocorrelation problems.

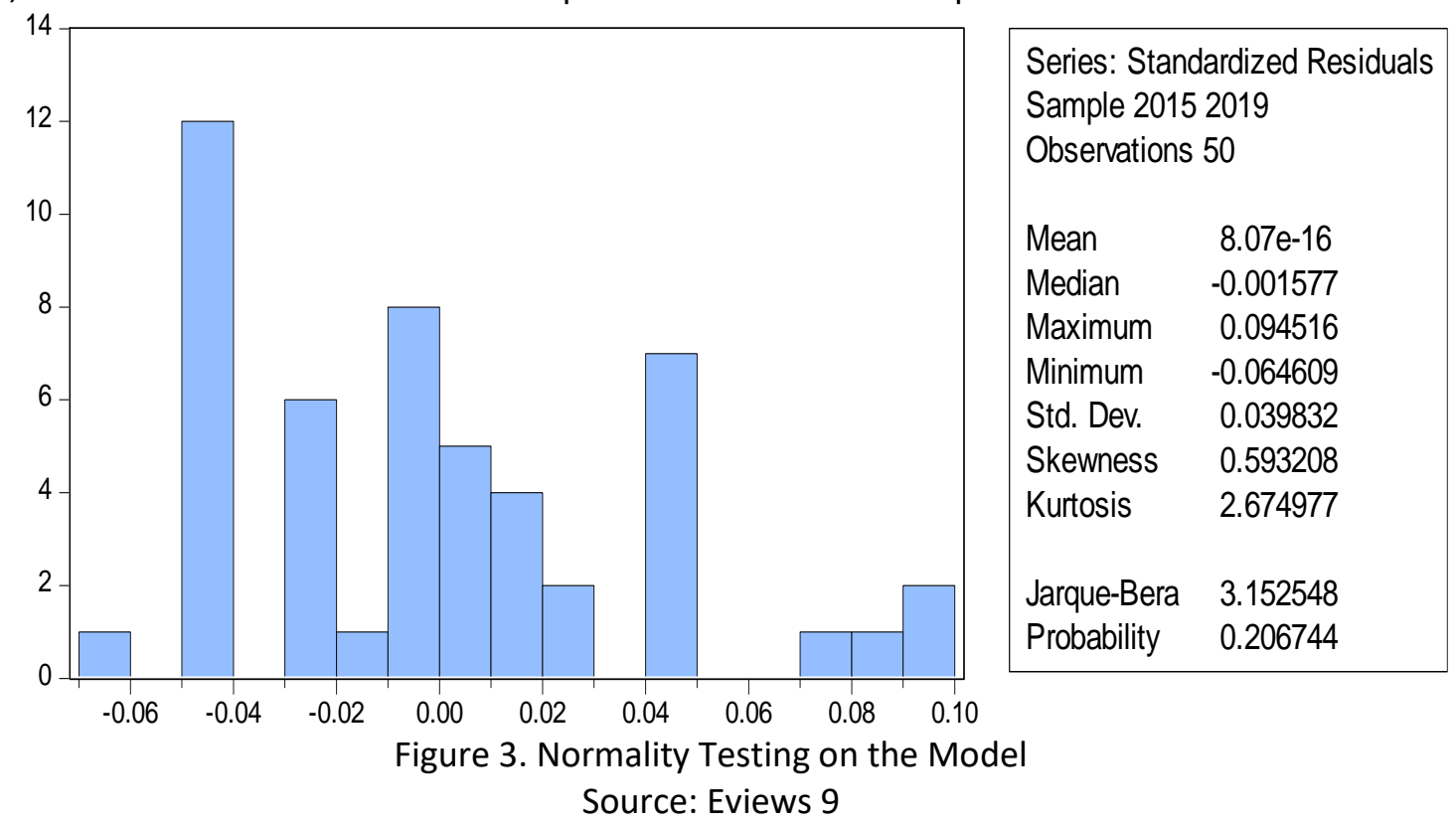

Normality test is to find out whether the residuals are normally distributed or not, normality testing is done using the Jarque-Bera method. The residual is said to have a normal distribution if Jarque Bera $<$ Chi square, and/or probability ( $p$-value) $>=5 \%$. of 0.206744 greater than 0.05 so it can be concluded that the remittance model for economic growth has a normal distribution of error terms.

\section{The Effect of Remittances on Economic Growth}

Based on the estimation results using panel data analysis, it can be seen that the amount of remittances affects economic growth positively and significantly. It can be proven by looking at the probability value with the remittance coefficient. The probability is 0.0174 less than the $5 \%$ significance level and the remittance variable coefficient is positive, which means that when remittances increase, economic growth will increase with the assumption that other variables do not change or cateris paribus. So it can be concluded that remittances have a positive and significant effect on economic growth. The increase in remittances can strengthen the balance of payments by providing foreign exchange for the country of origin of migrants and become a source of additional income for migrant families in the country of origin so as to encourage people's purchasing power which will increase economic growth. These results are in line with research conducted Abduvaliev \& Bustillo (2020) which states that remittances have a positive and significant effect on economic growth in former Soviet Union (CIS) countries. because they enjoy the opportunity to earn higher wages in the countries of destination. This research is also supported by research conducted Cooray (2012) and Tangtipongkul \& Khiev (2019). remittances are to be a catalyst for accelerated economic growth and development because they increase household income and purchasing power and serve as additional working capital for recipient households in the country of origin of the labor force. This is in accordance with the theory put forward by Keynes which says that expenses made by one person, will be directed at the income that will be received by others. When that person spends his income, he will basically provide income for others. This cycle will continue and will help to support increasing economic growth in a country.

\section{The Effect of Consumption on Economic Growth}

The estimation results using panel data analysis show that the amount of consumption affects positive and significant economic growth. It can be proven by looking at the probability value with the consumption coefficient. The probability is 0.0000 less than the $5 \%$ significance level and the 
consumption variable coefficient is positive, which means that when consumption increases, economic growth will increase with the assumption that other variables do not change or cateris paribus. So it can be concluded that consumption has a positive and significant effect on economic growth. An increase in consumption is important for the economy because an increase in consumption means an increase in demand for goods and services. An increase in demand for goods and services will encourage the economy to increase the production of goods and services so that it will lead to an increase in economic growth. Research conducted by Shera \& Meyer (2013) shows that consumption has a negative and significant effect on economic growth. However, subsequent research Meyer \& Shera (2017) shows that consumption has a positive and significant effect on economic growth because remittances increase income and encourage improvements made by households in daily consumption, spending on education, health, etc., so that it will affect economic growth.

\section{The Effect of FDI on Economic Growth}

Based on the estimation results using panel data analysis, it can be seen that the amount of Foreign Direct Investment (FDI) affects positive and significant economic growth. It can be proven by looking at the probability value with the Foreign Direct Investment (FDI) coefficient. The probability is 0.0000 less than the $5 \%$ significance level and the Foreign Direct Investment (FDI) variable coefficient is positive, which means that when the Foreign Direct Investment (FDI) increase, economic growth will increase with the assumption that other variables do not change or cateris paribus. So it can be concluded that Foreign Direct Investment (FDI) has a positive and significant effect on economic growth. An increase in investment is important for the economy because an increase in investment indicates an increase in capital formation. An increase in capital formation will result in an increase in the production of goods and services in the economy. This increase in the production of goods and services will lead to an increase in economic growth. These results are supported by research conducted by Shera \& Meyer (2013) which states that Foreign Direct Investment has a significant and positive effect on economic growth. Classical economic theory in foreign investment states that foreign investment as a whole benefits the economy and can increase the economic growth of the recipient country. Because foreign capital brought to the recipient country can be used for development purposes and the interests of the community. then foreign investment usually brings with it the technology contained in the country of the owner of the capital and disseminates the technology in the country of the recipient of the capital.

\section{CONCLUSIONS}

Remittances have a positive and significant effect on economic growth in ASEAN countries. In addition, consumption and Foreign Direct Investment (FDI) also have a positive and significant impact on economic growth in 10 ASEAN countries. Significant contribution of migrant remittances in economic growth if their use is directed to more productive sectors such as use in the investment sector can help the economies of ASEAN countries to maintain and increase economic growth. The government needs to improve the quality of migrant workers through education because a high level of education will affect the level of wages received by migrants and will have an impact on increasing remittances or remittances. In addition, providing socialization regarding the use of remittances to migrants so that remittances can provide far greater benefits for economic growth. Data for 2020 are not included in the data set used in the analysis. For this reason, it is better for further research to use 2020 data because in 2020 there is a new phenomenon, namely COVID-19 which can be traced to the impact of this phenomenon on remittances.

\section{ACKNOWLEDGEMENT}

Thanks to the adviser who always give encouragement and support to the Dr. Lies Maria Hamzah S.E, M.E and Dr. Arivina Ratih S.E, M.M, on the evaluation of this article, thanks also to the Faculty of Economics and Business, master of economics, University of Lampung, Indonesia. 


\section{REFERENCES}

Abduvaliev, M., \& Bustillo, R. (2020). Impact of remittances on economic growth and poverty reduction amongst CIS countries. Post-Communist Economies, 32(4), 525-546. https://doi.org/10.1080/14631377.2019.1678094

Abida, Z., \& Sghaier, I. M. (2014). Remittances, Financial Development and Economic Growth: The Case of North African Countries. The Romanian Economic Journal, XVII(51), 137-170.

Adenutsi, D. E. (2011). Financial development, international migrant remittances and endogenous growth in Ghana. Studies in Economics and Finance, 28(1), 68-89. https://doi.org/10.1108/10867371111110561

Afriska, A. E., Zulham, T., \& Dawood, T. C. (2019). Pengaruh Tenaga Kerja Indonesia Di Luar Negeri Dan Remitansi Terhadap Pdb Per Kapita Di Indonesia. Jurnal Perspektif Ekonomi Darussalam, 4(2), 231-248. https://doi.org/10.24815/jped.v4i2.12947

Akay, A., Giulietti, C., Robalino, J. D., \& Zimmermann, K. F. (2014). Remittances and well-being among rural-to-urban migrants in China. Review of Economics of the Household, 12(3), 517-546. https://doi.org/10.1007/s11150-013-9208-7

Cooray, A. (2012). The impact of migrant remittances on economic growth: Evidence from south asia. Review of International Economics, 20(5), 985-998. https://doi.org/10.1111/roie.12008

Dewi, E., Amar, S., \& Sofyan, E. (2013). Analisis Pertumbuhan Ekonomi, Investasi, dan Konsumsi di Indonesia. Jurnal Kajian Ekonomi, I(02), 176-193. http://ejournal.unp.ac.id/index.php/ekonomi/article/viewFile/752/621

Gujarati, D. (2013). Ekonometrika Dasar. Jakarta : Erlangga.

Meyer, D., \& Shera, A. (2017). The impact of remittances on economic growth: An econometric model. EconomiA, 18(2), 147-155. https://doi.org/10.1016/j.econ.2016.06.001

Permatasari, S. I., \& Sugiharti, L. (2017). Dampak Remitansi Tenaga Kerja Indonesia Terhadap Distribusi Pendapatan Rumah Tangga: Analisis Sistem Neraca Sosial Ekonomi Indonesia (SNSE) 2008. Jurnal IImu Ekonomi Terapan, 1(2), 51-64. https://doi.org/10.20473/jiet.v1i2.3299

Shera, A., \& Meyer, D. (2013). Remittances and their impact on economic growth. Periodica Polytechnica Social and Management Sciences, 21(1), 3-19. https://doi.org/10.3311/PPso.2152

Tangtipongkul, K., \& Khiev, V. (2019). The effect of remittance on economic growth in Cambodia. Journal of Population and Social Studies, 27(3), 232-246. https://doi.org/10.25133/JPSSv27n3.0015

Ukhtiyani, K., \& Indartono, S. (2020). Impacts of Indonesian Economic Growth: Remittances Migrant Workers and FDI. Jejak, 13(2), 280-291. https://doi.org/10.15294/jejak.v13i2.23543

Widarjono, A. (2013). Ekonometrika Pengantar dan Aplikasi : UPP STIM YKPN.

Winantyo, R., Saputra, R. D., \& Fitriani, S. (2015). Masyarakat Ekonomi ASEAN (MEA), Memperkuat sinergi ASEAN di tengah kompetisi global. Jakarta : PT. Alex Media Koputindo. 